\section{Receptor-specific Mediation by Immunoglobulin E of Antigen-induced Contraction of Tracheal and Lung Parenchymal Strips Isolated from the Guinea Pig}

F. M. Graziano, L. Gundersen, L. A. Larson, P. Harley, and C. K. Buckner

Department of Medicine, and School of Pharmacy,

The University of Wisconsin, Madison, Wisconsin 53792 bstract. The guinea pig is much like humans in the cells and mediators involved in immediate hypersensitivity reactions. However, the major anaphylactic antibody in this species is $\mathrm{IgG}_{1}$, not $\mathrm{IgE}$. Recently, we have been successful in producing IgE antibody in guinea pigs. The current study examined whether guinea pig IgE antibody could mediate pulmonary smooth muscle contraction. IgE antibody to picryl and oxazolone determinants was induced by immunizing Hartley strain guinea pigs pretreated with cyclophosphamide. Hyperimmune serum from these animals was passed through a heavy chain-specific anti-IgG ${ }_{1}$ affinity column. The presence of IgE anti-hapten antibody in the filtrate fraction was verified by passive cutaneous anaphylaxis (PCA) testing with a 7-d period of local passive sensitization and by heat lability $\left(56^{\circ} \mathrm{C} \times 4 \mathrm{~h}\right)$ of PCA activity. This IgE-rich fraction, and purified $\mathrm{IgG}_{1}$ anti-hapten antibody were transferred to normal guinea pigs. Both fractions sensitized trachea and pulmonary parenchyma for antigen-induced smooth muscle contraction. The $\mathrm{IgG}_{1}$-mediated antigeninduced contractile response was not affected by heat $\left(56^{\circ} \mathrm{C} \times 4 \mathrm{~h}\right)$ and was inhibited in a dose-dependent fashion by $\operatorname{IgG}_{1}$ blocking antibody (anti-OA). The IgEmediated antigen-induced contractile response was significantly decreased by heat and was not affected by the anti-OA blocking antibody even at a concentration of $100 \mathrm{mg} / \mathrm{kg}$.

This work was presented in part at the meetings of the American Academy of Allergy, Montreal, Canada, March 1982.

Received for publication 22 July 1983 and in revised form 22 December 1983.

J. Clin. Invest.

(c) The American Society for Clinical Investigation, Inc. 0021-9738/84/04/1215/08 $\$ 1.00$

Volume 73, April 1984, 1215-1222
Thus, two antigen-specific factors in guinea pig serum can mediate antigen-induced pulmonary smooth muscle contraction: $\operatorname{IgG}_{1}$ and IgE antibodies. Our data also suggests that these antibodies mediate the contractile response through separate receptors. The finding that guinea pig IgE can mediate pulmonary smooth muscle contraction suggests this species can be a model for IgE-mediated events in the lung.

\section{Introduction}

In humans, IgE is the principal antibody involved in antigenprovoked mediator release from the lung and appears important in the pathogenesis of asthma (1-2). The guinea pig has long been used as a model of human asthma since the airways from the two species respond in a similar way to a variety of contractile and relaxant substances (3). Furthermore, antigen-induced contraction of airway smooth muscle from the two species has been suggested to involve similar primary mediators-histamine and slow reacting substance of anaphylaxis (4-8). Unlike humans, however, the major homocytotropic antibody of the guinea pig is $\operatorname{IgG}_{1}(9-11)$.

The guinea pig, suitably sensitized, is known to be capable of producing IgE antibody (12-15). Guinea pig IgE is similar to human IgE in the length of time it persists in skin after passive sensitization and in loss of activity after reduction and alkylation or heat treatment (16). However, guinea pig IgE has been difficult to study because of the lack of a myeloma protein in this species.

Several recent studies have used the guinea pig, actively sensitized for the production of IgE antibody, as a model of human IgE-mediated pulmonary responses (17-21). A drawback to these studies is the fact that both $\mathrm{IgE}$ and $\mathrm{IgG}_{1}$ antibodies are produced to the antigen with the immunization protocol $(17,18)$. Therefore, in an actively sensitized animal, it is difficult to determine the contribution of each antibody to specific antigen responses.

We have produced IgE antibody in guinea pigs by pretreating the animals with cyclophosphamide and immunizing with low doses of antigen in alum (22). Furthermore, the IgE and $\mathrm{IgG}_{1}$ 
antibodies have been successfully separated by affinity chromatography (22), and the IgE antibody was demonstrated to mediate cutaneous basophil hypersensitivity (23) and histamine release from circulating basophils (24) of the guinea pig. In this communication, we report the ability of guinea-pig IgE to sensitize, via its own receptors, guinea-pig tracheal and lung parenchymal strips for antigen-induced contraction.

\section{Methods}

Animals. Outbred Hartley albino guinea pigs were obtained from BioLab Corp., St. Paul, MN. Females weighing 350-450 g were used throughout the study. Outbred New Zealand white rabbits used for some immunization procedures were obtained from Klubertanz Farms, Edgerton, WI. Animals were maintained by the Research Animal Resource Center of the University of Wisconsin.

Preparation of hapten-protein conjugates. An ascaris protein extract was prepared from a homogenized dessicate of whole worms (George S. Tulloch and Associates, San Antonio, TX) (22). To conjugate picryl or oxazolone groups to ascaris proteins, $10 \mathrm{ml}$ of the extract at $10 \mathrm{mg}$ / $\mathrm{ml}$ was adjusted to $\mathrm{pH} 9.0$ by addition of $5 \% \mathrm{Na}_{2} \mathrm{CO}_{3}$. Then, $0.5 \mathrm{ml}$ of $10 \%$ picryl chloride or oxazolone (Gallard Schlesinger, Carle Place, NY) in dioxane (Fisher Scientific Company, Pittsburgh, PA) was added dropwise while the $\mathrm{pH}$ was maintained at 9.0 by addition of $5 \% \mathrm{Na}_{2} \mathrm{CO}_{3}$. After stirring for $2 \mathrm{~h}$, the mixture was passed through a $2.4 \times 20-\mathrm{cm}$ column of Sephadex G-25 (Pharmacia Fine Chemicals, Piscataway, NJ) equilibrated with phosphate-buffered saline, $\mathrm{pH} 7.4$ (PBS). The conjugated material in the void volume was concentrated by negative pressure dialysis, and the protein content determined by the Micro-Kjeldahl method. The resulting picryl-Ascaris (Pic-Asc) ${ }^{1}$ and oxazolone-Ascaris (Ox-Asc) conjugates contained $1.1 \times 10^{-7}$ and $5 \times 10^{-7} \mathrm{~mol}$ of hapten/ $\mathrm{mg}$ of protein, respectively. Picryl (Pic) and oxazolone (Ox) haptens were conjugated to human serum albumin (Pic-HSA and Ox-HSA) in a manner similar to that described above.

Immunization procedures. Serum rich in IgE antibody to the haptenprotein conjugates Pic-Asc or Ox-Asc was obtained by a modification of techniques described previously (22). Briefly, 6-8 guinea pigs per group received an intraperitoneal injection of $250 \mathrm{mg} / \mathrm{kg}$ of cyclophosphamide (Mead Johnson, Evansville, IN) $2 \mathrm{~d}$ before primary intraperitoneal immunization with $1 \mu \mathrm{g}$ of conjugate adsorbed to $1 \mathrm{mg}$ of $\mathrm{Al}(\mathrm{OH})_{3}$ (alum) in $1 \mathrm{ml}$ of normal saline. Every month thereafter for $5 \mathrm{mo}$, a similar dose of antigen in alum was given intraperitoneally. $7 \mathrm{~d}$ after antigen injection in months 3,4 , and 5 , the animals were bled daily for $3 \mathrm{~d}$ by cardiac puncture. At the end of $5 \mathrm{mo}$, the animals were exsanguinated. The sera was stored in aliquots at $-90^{\circ} \mathrm{C}$ until time of use.

Serum rich in $\mathrm{IgG}_{1}$ antibody to ovalbumin (OA), Pic-guinea pig albumin, or Ox-guinea pig albumin was obtained with the immune deviation procedure as described previously (25). In this procedure, separate groups of guinea pigs were given a primary intraperitoneal immunization with $10 \mu \mathrm{g}$ of the respective antigen in Alum $(1 \mathrm{mg}) .2$ wk later, $50 \mu \mathrm{g}$ of antigen emulsified with complete Freund's adjuvant

1. Abbreviations used in this paper: alum, $\mathrm{Al}(\mathrm{OH})_{3}, \mathrm{CFA}$, complete Freund's adjuvant; $\mathrm{ED}_{50}$, median effective dose; ELISA, enzyme-linked immunosorbent assay; OA, ovalbumin; Ox, oxazolone; Ox-Asc, oxazolone-Ascaris; PCA, passive cutaneous anaphylaxis; Picryl; Pic-Asc, picryl-Ascaris.
(CFA) was injected into the four foot pads. Every $2 \mathrm{wk}$ for 2 mo thereafter, $50 \mu \mathrm{g}$ of antigen in CFA was injected subcutaneously in multiple sites on the animals. $7 \mathrm{~d}$ after the last injection, the animals were bled daily for $5 \mathrm{~d}$ by cardiac puncture. On the sixth day, the animals were exsanguinated. Serum obtained from the bleedings was stored at $-90^{\circ} \mathrm{C}$ until time of use.

Rabbit anti-guinea pig $\operatorname{IgG}_{1}$ antibody was prepared by immunizing rabbits monthly with subcutaneous injections of $500 \mu \mathrm{g}$ of columnpurified $\mathrm{IgG}_{1}$ (anti-OA) protein (see below) emulsified in CFA. Blood was obtained from ear veins, and serum was stored in aliquots at $-20^{\circ} \mathrm{C}$.

$I g G_{1}$ purification. $\mathrm{IgG}_{1}$ antibody was purified from immune serum by a combination of DE-52 cellulose (Whatman Laboratory Products, Inc., Clifton, NJ) and G-200 Sephadex (Pharmacia Fine Chemical) column chromatography by using modifications of methods described previously (22). Briefly, DE-52 cellulose columns $(2.4 \times 100 \mathrm{~cm})$ were equilibrated with $5 \mathrm{mM}$ phosphate buffer, $\mathrm{pH} 8.0$, at $4^{\circ} \mathrm{C}$. Immune serum equilibrated by dialysis with the same buffer was applied to the column and eluted in a stepwise fashion with the equilibrating buffer followed by $10 \mathrm{mM}, \mathrm{pH} 6.45 ; 40 \mathrm{mM}, \mathrm{pH} 6.2 ; 60 \mathrm{mM}, \mathrm{pH} 6.1 ; 0.1$ $\mathrm{M}, \mathrm{pH} 5.9$; and $0.3 \mathrm{M}$, pH 5.2 phosphate buffers. Those fractions rich in $\operatorname{IgG}_{1}$ antibody (fractions eluted by 10 and $40 \mathrm{mM}$ phosphate), as measured by Ouchterlony immunodiffusion using rabbit anti-IgG ${ }_{1}$, were pooled and rechromatographed on Sephadex G-200 equilibrated in 10 $\mathrm{mM}$ Tris, $0.2 \mathrm{M} \mathrm{NaCl}$ at $4^{\circ} \mathrm{C}$. A portion of the $\mathrm{IgG}_{1}$ fraction was iodinated by using lactoperoxidase and tested for purity by using sodium dodecyl sulfate-polyacrylamide gel electrophoresis. Use of murine myeloma immunoglobulin standards showed that $5-10 \%$ nonantibody protein contaminated the preparation.

Affinity column chromatography. The methods of Axen et al. (27) were used to prepare affinity columns. A guinea pig $\mathrm{IgG}_{2}$ affinity column was prepared by linking $\mathrm{IgG}_{2}$ (anti-OA) antibody, purified as described previously (26), to $50 \mathrm{~g}$ of Sepharose 4B (Pharmacia Fine Chemical) via cyanogen bromide. Upon completion of the coupling procedure, the Sepharose was treated with $1 \mathrm{M}$ ethanolamine for $2 \mathrm{~h}$ at $25^{\circ} \mathrm{C}$ and then washed with low $(0.2 \mathrm{M}$ acetate, $\mathrm{pH} 4.5)$ and high $(0.2 \mathrm{M}$ bicarbonate, $\mathrm{pH}$ 9) $\mathrm{pH}$ buffer solutions. The coupling efficiency of $\mathrm{IgG}_{2}$ antibody to Sepharose was $90 \%$.

Heavy chain-specific anti-guinea pig $\operatorname{IgG}_{1}$ was prepared by passing an $18 \% \mathrm{Na}_{2} \mathrm{SO}_{4}$ fraction of the rabbit antiserum through the $\mathrm{IgG}_{2}$ affinity column. The gamma globulin eluate was concentrated by negative pressure dialysis to $20 \mathrm{mg} / \mathrm{ml}$ and tested for heavy chain specificity by immunodiffusion against guinea pig $\mathrm{IgG}_{1}$ and $\mathrm{IgG}_{2}$ (both at $3 \mathrm{mg} / \mathrm{ml}$ ). Only one precipitin band to $\mathrm{IgG}_{1}$ was noted.

Anti-IgG ${ }_{1}$ affinity columns were prepared by linking $6 \mathrm{ml}(17 \mathrm{mg} /$ $\mathrm{ml}$ ) of the heavy chain-specific anti-IgG $1000 \mathrm{~g}$ of Sepharose $4 \mathrm{~B}$ with cyanogen bromide (88\% coupling efficiency). Upon completion of the coupling procedure, the Sepharose was treated with ethanolamine and washed with low and high $\mathrm{pH}$ buffer solutions as described above.

$\mathrm{IgG}_{1}$ was removed from guinea pig serum containing IgE antibody by slowly $(1.5-2 \mathrm{~h})$ passing the serum through an anti-IgG ${ }_{1}$ affinity column at $4^{\circ} \mathrm{C}$. The material passing through the column was concentrated to the original serum volume, and tested for residual $\mathrm{IgG}_{1}$ antibody by immunodiffusion against the rabbit anti-IgG ${ }_{1}$ and by enzyme-linked immunosorbent assay (ELISA). IgE antibody activity in this fraction was measured by using passive cutaneous anaphylaxis (PCA). The column was then washed thoroughly with $10 \mathrm{mM}$ PBS, $\mathrm{pH}$ 7.4. $\mathrm{IgG}_{1}$ bound to the affinity column was eluted with $10 \mathrm{ml}$ of $0.2 \mathrm{M}$ sodium carbonate $\left(\mathrm{Na}_{2} \mathrm{CO}_{3}\right)$, pH 11.3, which was subsequently removed from the preparation by dialysis against PBS.

$P C A$. PCA antibody titrations were performed as described by Ovary 
(28). Tenfold dilutions of the serum (in PBS) to be tested were made in test tubes and $0.1 \mathrm{ml}$ of each dilution was injected intradermally into the flank skin of $300-\mathrm{g}$ guinea pigs. A sensitization period of $4 \mathrm{~h}$ or 7 $\mathrm{d}$ was employed, and PCA reactions were developed by injecting intravenously $1 \mathrm{ml}$ of $0.5 \%$ Evans Blue containing $1 \mathrm{mg}$ of antigen. The PCA titer was taken as the highest dilution of antiserum giving a $6 \times 6-\mathrm{mm}$ blue reaction on the reflected skin surface in at least 3 of 4 recipients $(24,28)$. Heat sensitivity of the PCA antibody activity was determined by incubating antisera at $56^{\circ} \mathrm{C}$ for $4 \mathrm{~h}$ before performing dilutions for the PCA titration.

Quantitation and immunochemical identification of guinea pig $I g G_{1}$ A modification of a previously described ELISA method (29) was used to quantitate $\operatorname{IgG}_{1}$. Each well of plastic microtiter plates (Flow Laboratories, Inc., McLean, VA) was coated with $100 \mu l$ of purified IgG $_{1}$ (anti-OA, $25 \mu \mathrm{g} / \mathrm{ml}$ ) in carbonate buffer, $\mathrm{pH}$ 9.0. Sites on the well surface not bound by $\mathrm{IgG}_{1}$ protein were saturated by the addition of $10 \%$ bovine serum albumin (BSA) in carbonate buffer. Coated plates were washed with PBS containing $0.05 \%$ Tween $20, \mathrm{pH} 7.5$, and aspirated dry. A competitive binding standard curve for $\mathrm{IgG}_{1}$ was obtained by adding purified $\mathrm{IgG}_{1}$ at various concentrations $(10 \mathrm{ng}-1 \mathrm{mg} / \mathrm{ml})$ to test tubes containing a 1:50 dilution of heavy chain-specific rabbit anti-guinea pig $\mathrm{IgG}_{1}$. After incubation at $37^{\circ} \mathrm{C}$ for $1 \mathrm{~h}$ and subsequent centrifugation, $100 \mu \mathrm{l}$ of the adsorbed anti-IgG $\mathrm{I}_{1}$ was added to the $\mathrm{IgG}_{1}$-coated plates. The plates were incubated at $37^{\circ} \mathrm{C}$ for $1 \mathrm{~h}$ and subsequently, washed three times. Horseradish peroxidase (Sigma Chemical Co., St. Louis, MO) conjugated sheep anti-rabbit Fc (100 $\mu$ l, diluted $1 / 1000$ in PBS with $5 \% \mathrm{BSA}$ ) was added to the wells and the plates were incubated at $37^{\circ} \mathrm{C}$ for $30 \mathrm{~min}$. After three washes, $100 \mu \mathrm{l}$ of 2,2-Azino-di(3-ethylbenzthiazdinesulfonic acid) in a $0.05 \mathrm{M}$ citrate buffer, $\mathrm{pH} 4.0$, was added to each well and the reaction allowed to develop for $30 \mathrm{~min}$ at room temperature. The reaction was stopped by the addition of $100 \mu \mathrm{l}$ of $0.001 \mathrm{M}$ editic acid in $0.1 \mathrm{M}$ hydrofluoric acid. Optical density was measured at $414 \mathrm{~nm}$ in a micro-sampling spectrophotometer (Guilford, Oberlin, $\mathrm{OH}$ ). This assay could detect $10-20 \mathrm{ng}$ of $\mathrm{IgG}_{1}$ per milliliter.

Immunodiffusion and immunoelectrophoresis in agar (1\% purifiedDifco Certified, Difco Laboratories, Inc., Detroit, MI) were performed on 2.5-cm slides as described previously (26). IgG protein concentration determinations were performed according to the method of Lowry et al. (30).

Measurement of tracheal and parenchymal smooth muscle contraction. Normal guinea pigs were given intravenous injections of $3 \mathrm{ml} / \mathrm{kg}$ of either unadsorbed IgE-rich serum, heated $\left(56^{\circ} \mathrm{C} \times 4 \mathrm{~h}\right)$ or nonheated IgE-rich serum after adsorption with anti-IgG, linked to Sepharose, or with varying doses of affinity column or DE-52, G-200 Sephadex-purified $\mathrm{IgG}_{1}$. The animals were sacrificed 1,4 , or $7 \mathrm{~d}$ later and the proximal half of the trachea and lower right lung lobe removed. Tracheal segments were trimmed of excess tissue and cut in a spiral fashion. One parenchymal strip, containing the pleural edge and measuring $\sim 3 \times 3 \times 20$ $\mathrm{mm}$, was cut from the lung lobe. The techniques have been previously described $(31,32)$.

Each strip was suspended vertically in a 10-ml water-jacketed (37$38^{\circ} \mathrm{C}$ ) tissue bath containing a physiological salt solution of the following composition: $\mathrm{NaCl}, 118 \mathrm{mM} ; \mathrm{KCl}, 4.7 \mathrm{mM} ; \mathrm{CaCl}_{2} \cdot 2 \mathrm{H}_{2} \mathrm{O}, 2.5 \mathrm{mM}$; $\mathrm{MgCl}_{2} \cdot 6 \mathrm{H}_{2} \mathrm{O}, 0.5 \mathrm{mM} ; \mathrm{NaH}_{2} \mathrm{PO}_{4} \cdot \mathrm{H}_{2} \mathrm{O}, 1 \mathrm{mM} ; \mathrm{NaHCO}_{3}, 25 \mathrm{mM}$ glucose, $11 \mathrm{mM}$. The solution bathing the tissue and the stock salt solution were gassed with a mixture of oxygen ( $95 \%$ ) and carbon dioxide (5\%). Initial tensions on the tracheal and parenchymal strips were adjusted to 5 and $2 \mathrm{~g}$, respectively, and maintained at these levels throughout a 90-120-min equilibration period. Changes in tension were recorded via force transducers (FT-03) on a Grass model 5D or 7C polygraph.
Cumulative dose-response effects of antigen were obtained by increasing the concentration by a factor of 10 after the effect of the previous concentration reached a plateau (33). Only one cumulative dose-response curve was obtained on each strip. Responses to each concentration of antigen were calculated as a percentage of the maximum contraction produced in the trachea by carbachol, $10^{-3} \mathrm{M}$, and in the parenchymal strip by histamine, $10^{-3} \mathrm{M}$, both added at the end of each experiment.

Median effective dose $\left(E D_{50}\right)$ values were obtained visually from a plot of log concentration (milligrams per milliliter) vs. percent of the maximum response produced by the antigen. All $\mathrm{ED}_{s 0}$ values were converted to negative $\log$ values $\left(-\log E D_{s_{0}}\right)$ and standard errors of the mean calculated for values obtained in each series of experiments. Differences between two means were determined using Student's $t$ test for unpaired samples.

Inhibition studies were conducted by injecting intravenous various doses of competing $\operatorname{IgG}_{1}$ (anti-OA) into normal guinea pigs $\sim 30 \mathrm{~min}$ before injecting intravenous $3 \mathrm{ml} / \mathrm{kg}$ of either unadsorbed IgE-rich serum, nonheated $\mathrm{IgE}$-rich serum after adsorption with anti-IgG, linked to Sepharose, or with $1 \mathrm{mg} / \mathrm{kg}$ of purified $\mathrm{IgG}_{1}$ (anti-Ox). The animals were sacrificed the following day (20-24 h), and measurement of tracheal and parenchymal smooth muscle contraction was performed as described above.

\section{Results}

Affinity column adsorption of $I g G_{1}$ from IgE-rich serum. Guinea pigs pretreated with cyclophosphamide and immunized with monthly intraperitoneal injections of either Pic-Asc or Ox-Asc in alum had peak, heat-labile, 7-d sensitization PCA titers, representing IgE responses, at months 4 and 5 of the immunization protocol. $\mathrm{IgG}_{1}$ antibody is also produced in response to this protocol (22). Therefore, to exclude the participation of $\mathrm{IgG}_{1}$, serum rich in IgE was passed through an affinity column of

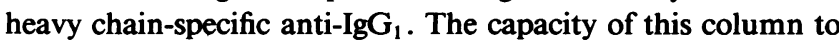
deplete guinea pig serum of $\mathrm{IgG}_{1}$ antibody was measured by serial passage of $0.2 \mathrm{ml}$ serum aliquots through a column containing $10 \mathrm{ml}$ of antibody-linked Sepharose. Immunodiffusion and ELISA analysis showed that virtually all the $\mathrm{IgG}_{1}$ in $1 \mathrm{ml}$ of serum was adsorbed by this column.

When adsorbing IgG $_{1}$ from IgE-rich serum, $50 \mathrm{ml}$ of antiIgG $_{1}$ affinity column was underloaded with $4 \mathrm{ml}$ of immune serum to obtain complete adsorption of $\mathrm{IgG}_{1}$ antibody. Material passing through such a column was concentrated to the original starting volume (4 ml) and tested for the presence of IgE antibody by evaluating PCA activity in heated $\left(56^{\circ} \mathrm{C} \times 4 \mathrm{~h}\right)$ and nonheated samples. In Fig. 1, it can be observed that unadsorbed antiserum (heated or nonheated) produced significant PCA titers when a 4-h sensitization period was used, and had some heat-stable PCA activity when a 7-d sensitization period was used. This suggests the presence of $\operatorname{IgG}_{1}$ antibody that is heat insensitive and also IgE antibody that is heat sensitive. Column-adsorbed serum retained PCA activity at 4-h and 7-d skin sensitization periods and this PCA activity was completely heat-labile (Fig. 1). Accordingly, our adsorbed serum contains PCA activity that is due to IgE and not $\operatorname{IgG}_{1}$ antibody, and this is as we have described previously (22). The PCA activity of serum samples 


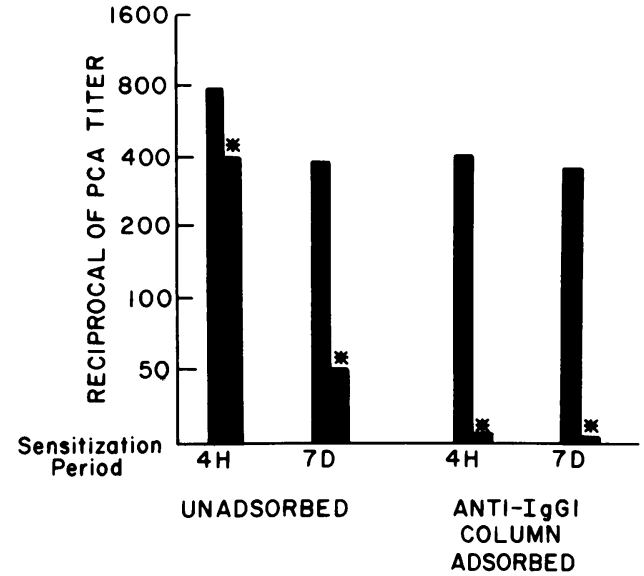

Figure 1. 4-h and 7-d sensitization period PCA titers of unadsorbed

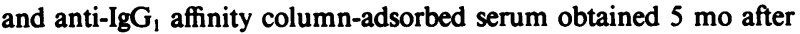
immunization for IgE antibody response by cyclophosphamide pretreatment and monthly injection of guinea pigs with $1 \mu \mathrm{g}$ Pic-Asc plus Alum. *, heated IgE-rich serum.

was evaluated prior to being used in studies measuring pulmonary smooth muscle contraction.

Unadsorbed sera obtained from three animals immunized for $\mathrm{IgG}_{1}$ antibody by using immune deviation were found to have 4-h PCA titers ranging from 1:1600 to 1:3200. These titers were unaffected by heating the serum at $56^{\circ} \mathrm{C} \times 4 \mathrm{~h}$. PCA titers of these sera with a 7-d sensitization period were 1:20 to 1:50. Adsorption of the sera with an anti-IgG ${ }_{1}$ affinity column eliminated all PCA activity. These data strongly suggest that IgE antibody is not present in the $\mathrm{IgG}_{1}$ antisera.

Immunochemical identification and quantitation of $I g G_{l}$. Ouchterlony immunodiffusion analysis using heavy chain-specific rabbit anti-guinea pig IgG $_{1}$ in the center well consistently resulted in a strong precipitin line of identity against unadsorbed serum and guinea pig $\operatorname{IgG}_{1}$. No lines were observed against purified $\mathrm{IgG}_{2}$ or concentrated IgE-rich serum, that was depleted of $\mathrm{IgG}_{1}$ by adsorption with the anti-IgG ${ }_{1}$ column. It has been shown previously that as little as $35 \mu \mathrm{g}$ of purified $\mathrm{IgG}_{1}$ can transfer cutaneous basophil hypersensitivity (34), and in the current study, $0.01 \mathrm{mg} / \mathrm{kg}$ of purified $\mathrm{IgG}_{1}$ could transfer to normal animals a detectable pulmonary smooth muscle contraction. This amount of antibody is below the detection limits of the Ouchterlony gel diffusion system; thus, a competitive binding ELISA assay was established to measure lower levels of $\mathrm{IgG}_{1}$ that might be present in adsorbed serum.

The lower limit of detection of $\mathrm{IgG}_{1}$ in the ELISA was 10$20 \mathrm{ng} / \mathrm{ml}$. The concentration of $\mathrm{IgG}_{1}$ in unadsorbed IgE-rich serum was found to be $500-1,100 \mu \mathrm{g} / \mathrm{ml}$. When this serum was depleted of $\operatorname{IgG}_{1}$ by passage through the anti-IgG ${ }_{1}$ affinity column, IgG $_{1}$ levels were consistently $<20 \mathrm{ng} / \mathrm{ml}$. All columnadsorbed sera were assayed similarly before being used in any study.
Guinea pig $\mathrm{IgG}_{1}$ bound to the anti-IgG $\mathrm{I}_{1}$ affinity column was eluted with $0.2 \mathrm{M} \mathrm{Na}_{2} \mathrm{CO}_{3}, \mathrm{pH}$ 11.3. The eluates from multiple columns were concentrated back to the original volume and pooled. Immunoelectrophoretic analysis of this material vs. either rabbit anti-guinea pig whole serum, heavy chain-specific anti-IgG ${ }_{2}$, or anti-IgG 1 , revealed only $\operatorname{IgG}_{1}$ to be present in this fraction. The protein concentration of the preparation by Lowry assay was $820 \mu \mathrm{g} / \mathrm{ml}$, and the $\operatorname{IgG}_{1}$ content by ELISA was 710 $\mu \mathrm{g} / \mathrm{ml}$.

Tracheal and parenchymal strip contractions. Preliminary experiments $(n=18)$ were conducted to establish the optimum dose of $\mathrm{IgG}_{1}$ antibody that could sensitize pulmonary smooth muscle for antigen-induced contraction. Purified IgG $_{1}$ anti-picryl or anti-oxazolone antibodies were administered in doses of $0.001-6 \mathrm{mg} / \mathrm{kg}$ at $1 \mathrm{~d}$ prior to isolation of tracheal and parenchymal strips. From this series of experiments, we found that detectable contractions of tracheal and parenchymal strips $(7 \%$ of maximum) to hapten antigen could be obtained with 0.01 $\mathrm{mg} / \mathrm{kg}$ of antibody. No responses were observed with $0.001 \mathrm{mg} /$ $\mathrm{kg}$ of the $\mathrm{IgG}_{1}$ antibody. The maximum contractile responses to antigen increased with antibody dose. A dose of $1 \mathrm{mg} / \mathrm{kg}$ of $\operatorname{IgG}_{1}(n=4)$ consistently resulted in maximum responses to antigen of $60-70 \%$ (Fig. 2 and Table I). While doses of 2 and $6 \mathrm{mg} / \mathrm{kg}(n=6)$ of $\mathrm{IgG}_{1}$ occasionally resulted in slightly larger responses $(82 \pm 6 \%)$, the remainder of the study was conducted using $1 \mathrm{mg} / \mathrm{kg}$ of $\operatorname{IgG}_{1}$ to passively sensitize the animals.

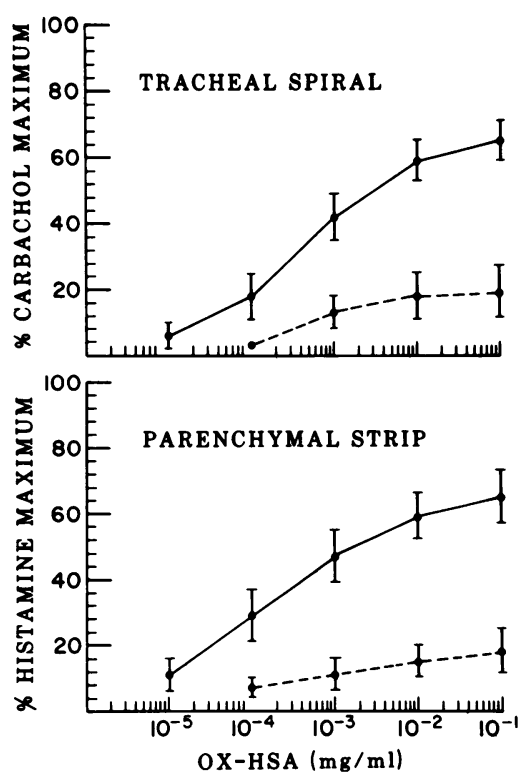

Figure 2. Log dose-response curves for Ox-HSA in producing contraction of guinea pig tracheal spirals and parenchymal strips. Animals were treated with $1 \mathrm{mg} / \mathrm{kg}$ purified anti-Ox $\mathrm{IgG}_{1}$ alone $(-)$ or with $9-15 \mathrm{mg} / \mathrm{kg}$ purified anti-OA IgG, before the anti-Ox IgG $(---)$ at $1 \mathrm{~d}$ before the experiment. Vertical lines indicate SEM and the data are summarized in Table $I$. 
Table I. Summary of Ox-HSA-induced Contractile Response in Trachea and Parenchyma

\begin{tabular}{|c|c|c|c|c|c|c|}
\hline \multicolumn{2}{|c|}{ Treatment* } & \multicolumn{2}{|c|}{ Trachea } & \multicolumn{2}{|c|}{ Parenchyma } & \multirow[b]{2}{*}{ No." } \\
\hline Anti-Ox antibody & Antagonist & $-\log E D_{s_{0}} \neq \pm S E M$ & $\%$ maximum $\S \pm$ SEM & $-\log \mathrm{ED}_{\mathrm{so}_{0} \neq \pm \mathrm{SEM}}$ & $\%$ Maximum $\S$ SEM & \\
\hline $1 \mathrm{mg} / \mathrm{kg} \mathrm{IgG}_{1}$ & - & $3.37 \pm 0.20$ & $65 \pm 6$ & $3.81 \pm 0.21$ & $65 \pm 8$ & 7 \\
\hline $1 \mathrm{mg} / \mathrm{kg} \mathrm{IgG}$ & $\begin{array}{l}9-15 \mathrm{mg} / \mathrm{kg} \\
\operatorname{lgG}_{1} \text { anti-OA }\end{array}$ & $3.60 \pm 0.25$ & $19 \pm 8 \pi$ & $3.70 \pm 0.40$ & $18 \pm 7 \pi$ & 6 \\
\hline $\begin{array}{l}3 \mathrm{ml} / \mathrm{kg} \text { adsorbed } \\
\text { IgE filtrate }\end{array}$ & - & $3.45 \pm 0.13$ & $57 \pm 8$ & $3.60 \pm 0.19$ & $64 \pm 6$ & 8 \\
\hline $\begin{array}{l}3 \mathrm{ml} / \mathrm{kg} \text { adsorbed } \\
\mathrm{IgE} \text { filtrate }\end{array}$ & $\begin{array}{c}50 \mathrm{mg} / \mathrm{kg} \mathrm{IgG} \\
\text { anti-OA }\end{array}$ & $3.62 \pm 0.19$ & $67 \pm 8$ & $3.75 \pm 0.23$ & $49 \pm 5$ & 7 \\
\hline $\begin{array}{l}3 \mathrm{ml} / \mathrm{kg} \text { unadsorbed } \\
\text { IgE serum }\end{array}$ & - & $3.62 \pm 0.18$ & $83 \pm 2$ & $3.36 \pm 0.19$ & $70 \pm 2$ & 6 \\
\hline $\begin{array}{l}3 \mathrm{ml} / \mathrm{kg} \text { unadsorbed } \\
\text { IgE serum }\end{array}$ & $\begin{array}{l}50 \mathrm{mg} / \mathrm{kg} \mathrm{IgG} \mathrm{I}_{1} \\
\text { anti-OA }\end{array}$ & $3.52 \pm 0.12$ & $78 \pm 3$ & $3.42 \pm 0.27$ & $62 \pm 7$ & 8 \\
\hline
\end{tabular}

* All animals were passively sensitized with antibody intravenously. When IgG 1 anti-OA was administered, it was given 30 min before anti-Ox antibody. $¥$ Negative logarithm of the concentration of Ox-HSA (milligrams per milliliter) required to produce a response equal to $50 \%$ of its own maximum contraction. \& Percent maximum response produced by Ox-HSA relative to the maximum contraction produced by carbachol (trachea) or histamine (parenchyma). "Number of observations. T Designates value that is statistically different $(P<0.05)$ from that immediately preceeding in the same column.

Adsorbed IgE-rich serum containing $<20 \mathrm{ng} / \mathrm{ml}$ of $\mathrm{IgG}_{1}$ antibody (ELISA) was administered in doses of $1-15 \mathrm{ml} / \mathrm{kg}$ at 1,4 , or $7 \mathrm{~d}$ prior to isolation of the tracheal and parenchymal strips. A dose of $3 \mathrm{ml} / \mathrm{kg}(n=6)$ was found to optimally sensitize the tissues and resulted in maximum responses to antigen (PicHSA or Ox-HSA; data shown only for Ox-HSA) of $\sim 40-60 \%$ (Fig. 3 and Table I). Contractile responses were similar when examined at all three time periods after serum administration. Usually, tissues isolated from animals sensitized with $<3$ $\mathrm{ml} / \mathrm{kg}$ contracted $10-30 \%$ at maximum antigen concentrations. Doses $>3 \mathrm{ml} / \mathrm{kg}$ did not result in an increase in the maximum antigen-provoked contractions.

Contractions to the antigens were not observed when guinea pigs were injected with serum taken from unimmunized animals ( $3 \mathrm{ml} / \mathrm{kg}, 1 \mathrm{~d}$ ), anti-hapten serum obtained from animals immunized for $\mathrm{IgG}_{1}$ production and depleted of $\mathrm{IgG}_{1}$ by an anti$\mathrm{IgG}_{1}$ affinity column ( $\left.3 \mathrm{ml} / \mathrm{kg}, 1 \mathrm{~d}\right)$, or with $\mathrm{IgG}_{2}$ purified from anti-hapten serum $(30 \mathrm{mg} / \mathrm{kg}, 1 \mathrm{~d})$. Furthermore, neither PicHSA nor Ox-HSA caused contractions of strips taken from animals not passively sensitized with antibody. The specificity of the responses was further verified by the demonstration that contractions could not be elicited to an extraneous antigen (OA) in tissues taken from animals sensitized with anti-hapten IgG $_{1}$ or IgE.

Heat sensitivity of IgE-mediated, antigen-induced pulmonary contractions. Heat treatment $\left(56^{\circ} \mathrm{C} \times 4 \mathrm{~h}\right)$ of anti-Pic IgE-rich serum after adsorption with anti-IgG $\mathrm{I}_{1}$ linked to Sepharose resulted in a marked reduction in the contractile responses to antigen in the guinea pig tissues. Peak contractions to Pic-HSA in the trachea and parenchyma were $49 \pm 6$ and $42 \pm 7 \%$ of maximum, respectively, when the tissues were taken from animals receiving $3 \mathrm{ml} / \mathrm{kg}$ of unheated adsorbed serum $(n=3)$. The respective values were $19 \pm 7$ and $18 \pm 6 \%$ of maximum when animals received an equal dose of heated, adsorbed serum ( $n$ $=5$ ). Similar heat treatment of purified IgG $_{1}$ anti-hapten antibody $(1 \mathrm{mg} / \mathrm{kg}, 1 \mathrm{~d})$ did not alter the contractile response to antigen $(n=4)$.

Inhibition of positive sensitization. Having established that two antigen-specific factors in guinea pig serum can sensitize pulmonary smooth muscle for a contractile response on exposure to antigen, we sought to determine if these antibody-mediated responses could be inhibited by IgG $_{1}$ of an extraneous specificity. Results of inhibition experiments by using purified guinea pig anti-OA IgG $_{1}$ as blocking antibody are illustrated in Figs. 2-4 and summarized in Table I. There was substantial inhibition of the ability of Ox-HSA to contract tissues taken from animals passively sensitized with purified anti-Ox IgG $_{1}$ antibody $(1 \mathrm{mg} / \mathrm{kg}, 1 \mathrm{~d}$ ) after administration of $9-15 \mathrm{mg} / \mathrm{kg}$ of anti-OA $\mathrm{IgG}_{1}$ (Fig. 2 and Table I). Doses of 3 and $6 \mathrm{mg} / \mathrm{kg}$ of anti-OA did not alter contractions to Ox-HSA. Doses of 50 and $100 \mathrm{mg} /$ $\mathrm{kg}$ completely abolished contraction in four animals sensitized with $1 \mathrm{mg} / \mathrm{kg}$ of anti-Ox $\mathrm{IgG}_{1}$ antibody. At the end of each experiment, the tracheal and parenchymal strips were exposed to $O A\left(10^{-1} \mathrm{mg} / \mathrm{ml}\right)$ and substantial contractions were observed.

In contrast, doses of 50 and $100 \mathrm{mg} / \mathrm{kg}$ of anti-OA $\mathrm{IgG}_{1}$ given before either unadsorbed or adsorbed ( $<20 \mathrm{ng} \mathrm{IgG}_{1}$-ELISA) IgE-rich anti-Ox serum $(3 \mathrm{ml} / \mathrm{kg})$ did not result in a change in the dose-response curves to the antigen Ox-HSA (Figs. 3 and 4 and Table I).

In an additional experiment, the $\mathrm{IgG}_{1}$ anti-Ox antibody adsorbed from IgE-rich serum was desorbed from the anti-IgG $G_{1}$ affinity column and its identity confirmed by immunoelectro- 

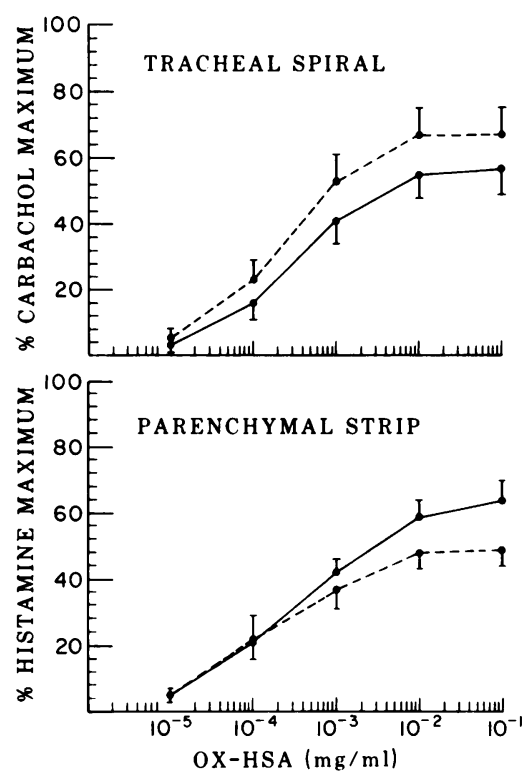

Figure 3. Log dose-response curves for Ox-HSA in producing contraction of guinea pig tracheal spirals and parenchymal strips. Animals were treated with $3 \mathrm{ml} / \mathbf{k g}$ anti-IgG $\mathrm{G}_{1}$ affinity column-adsorbed IgE-rich serum (anti-Ox) alone (-) or with $50 \mathrm{mg} / \mathrm{kg}$ purified anti$O A \mathrm{IgG}_{1}$ before the adsorbed serum (- - ) at $1 \mathrm{~d}$ before the experiment. Vertical lines indicate SEM and the data are summarized in Table I.

phoresis and ELISA. This antibody in a dose of $1 \mathrm{mg} / \mathrm{kg}$ was injected into four animals. Two of the animals also received anti-OA $\mathrm{IgG}_{1}, 50 \mathrm{mg} / \mathrm{kg}, 30 \mathrm{~min}$ beforehand. One day later, Ox-HSA-induced contractions in isolated tracheal and parenchymal strips were evaluated. The results are not shown, but are similar to those described above for the inhibition of antiOx $\operatorname{IgG}_{1}$. Contractions to Ox-HSA were not observed in tissues taken from animals pretreated with anti-OA $\mathrm{IgG}_{1}$ antibody.

\section{Discussion}

This study has demonstrated that two factors in guinea pig serum can sensitize pulmonary smooth muscle for antigen-induced contraction. Our results provide strong evidence that these factors are $\operatorname{IgG}_{1}$ and IgE antibodies. Furthermore, we have provided evidence that $\operatorname{IgG}_{1}$ and IgE sensitize pulmonary tissues by attaching to different receptors.

Since there have been no myeloma proteins described in the guinea pig, IgE antibody can be defined only by characteristics it has in common with IgE from other species: PCA activity after a prolonged sensitization period in skin, loss of PCA activity after heating or reduction and alkylation of the antibody, and passage of PCA activity through an affinity chromatography column that removes $\operatorname{IgG}_{1}$ antibody $(22,28)$. Each of these conditions has been satisfied in this study for PCA as well as for antigen-induced tracheal and parenchymal strip contractions.
Since $\mathrm{IgG}_{1}$ is the major anaphylactic antibody in the guinea pig and is produced in significant concentrations in any IgEproducing immunization protocol (22), it was imperative to deplete the preparation of $\operatorname{IgG}_{1}$ in order to study the properties of IgE. Effective removal of $\mathrm{IgG}_{1}$ by affinity chromatography in our study was demonstrated by ELISA. Residual IgG $_{1}$ in serum after adsorption was $<10-20 \mathrm{ng}$; a depletion of $\sim 99.995 \%$. The amount of $\operatorname{IgG}_{1}$ antibody remaining in affinity column adsorbed serum was approximately 1,000 times less than the smallest amount of $\operatorname{IgG}_{1}$ that could sensitize for detectable tracheal and parenchymal strip contraction. Therefore, it is unlikely that sensitization by IgE-rich adsorbed serum was due to contaminating $\operatorname{IgG}_{1}$. IgE anti-hapten activity in the $\operatorname{IgG}_{1}$-depleted serum was measured by PCA activity that was destroyed by heat. Injection of adsorbed IgE filtrates into normal animals passively sensitized trachea and parenchyma at 1,4 , and $7 \mathrm{~d}$ for antigen-induced contraction. This effect was heat-sensitive. Although antigen-induced contraction was obtained with purified anti-hapten $\mathrm{IgG}_{1}$ antibody at 1,4 , and $7 \mathrm{~d}$, this was resistant to heat treatment and absent after adsorption with an anti-IgG affinity column.

Katayama et al. (35) have shown that a non- $\operatorname{IgG}_{1}$, non-IgE serum factor can mediate cutaneous basophil hypersensitivity reactions. These reactions have previously been shown to be mediated only by immune lymphocytes and antibody (36). The serum factor of Katayama et al. has been shown to be antigen specific, to have a molecular weight of 70,000 , to be present in

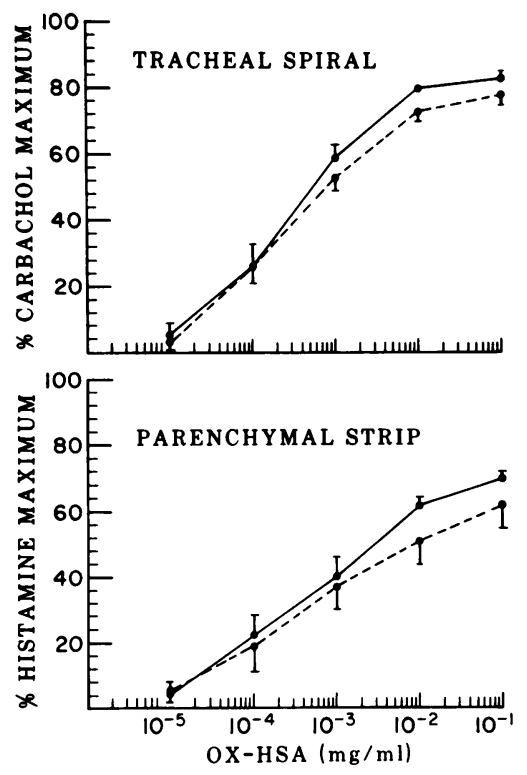

Figure 4. Log dose-response curves for Ox-HSA in producing contraction of guinea pig tracheal spirals and parenchymal strips. Animals were treated with $3 \mathrm{ml} / \mathrm{kg}$ unadsorbed IgE-rich serum (anti-Ox) alone $(-)$ or with $50 \mathrm{mg} / \mathrm{kg}$ purified anti-OA $\mathrm{IgG}_{1}$ before the unadsorbed serum (-- ) at $1 \mathrm{~d}$ before the experiment. Vertical lines indicate SEM and the data are summarized in Table I. 
immune serum for only a short period of time after sensitization ( $\sim 1 \mathrm{wk}$ ), and to be absent from the globulin fraction of serum. There is no evidence that this factor is heat-sensitive or remains in tissues for a prolonged period of time. In our work, the antigen-induced pulmonary smooth muscle contraction mediated by adsorbed IgE-rich serum met all the criteria for the definition of IgE antibody in the guinea pig. Furthermore, serum from animals immunized for IgG alone (no IgE as shown by PCA) and passed through an anti-IgG ${ }_{1}$ affinity column failed to sensitize pulmonary tissues for antigen-induced contraction. Therefore, our data do not support the existence of another factor in guinea pig serum capable of sensitizing pulmonary tissue.

Since a myeloma protein for IgE in the guinea pig is not available, we have not performed inhibition studies with purified IgE preparations. Nevertheless, results from our inhibition studies provide strong evidence for the existence of two distinct receptors for $\mathrm{IgG}_{1}$ and $\mathrm{IgE}$ in the guinea pig pulmonary systems examined. These data also emphasize and strengthen the interpretation that two different factors in guinea pig serum can sensitize for antigen-induced smooth muscle contraction. The inhibition by anti-OA $\mathrm{IgG}_{1}$ of the ability of anti-Ox $\mathrm{IgG}_{1}$ to sensitize the pulmonary tissues cannot be attributed to a nonspecific effect since anti-OA $\mathrm{IgG}_{1}$ did not alter sensitization by adsorbed IgE filtrate or unadsorbed IgE-rich serum. Furthermore, substantial OA-induced contraction was observed in the tissues that did not respond (or weakly contracted) to Ox-HSA. These observations would appear to rule out an alteration by blocking antibody of the desensitization process occurring during cumulative antigen administration.

Since both IgE and IgG $_{1}$ anti-hapten antibodies are present in hyperimmune serum and both can mediate a contractile response in pulmonary smooth muscle, it is likely that blockade of sensitization by either antibody alone is not adequate to inhibit antigen-specific contraction. This is supported by the observation that anti-OA $\operatorname{IgG}_{1}$ did not alter responses to $\mathrm{Ox}$ HSA in animals receiving unadsorbed IgE-rich serum. In these experiments, the contractile response observed in tissues taken from animals receiving the blocking antibody was probably mediated by IgE.

Since we have demonstrated that IgE antibody can sensitize guinea pig pulmonary tissues for antigen-induced contraction, this system can now be further examined as a possible model for IgE-mediated events in the human lung. In our studies, there was little difference in antigen sensitivity or maximum antigeninduced contraction between tracheal and parenchymal strips or between $\mathrm{IgG}_{1}$ - and IgE-mediated contractions. However, this does not provide information about mediators released or cell types activated by antigen. Furthermore, the magnitude of desensitization occurring during cumulative antigen administration cannot be ascertained from these studies. Preliminary work has suggested differences in mediator release between $\operatorname{IgG}_{1}$ and IgEsensitized guinea pig pulmonary tissues (19-21, 37). Additional studies will be needed for a proper comparison of IgE-mediated events in guinea pig and human lung.

\section{Acknowledgments}

This work was supported in part by a Young Investigator National Institutes of Health grant (AI-16311), an American Lung Association grant, and a National Institutes of Health Allergic Disease Center grant (AI-10404-12).

\section{References}

1. Ishizaka, K. 1976. Cellular events in the IgE antibody response. Adv. Immunol. 23:1-75.

2. Kay, A. B., and K. F. Austen. 1971. The IgE-mediated release of an eosinophil leucocyte chemotactic factor from human lung. J. Immunol. 107:899-902.

3. Church, M. K. 1975. Responses of rat lung to humoral mediators of anaphylaxis and its modification by drugs and sensitization. $B r$. $J$. Pharmacol. 55:423-435.

4. Collier, H. O., and G. W. L. James. 1967. Humoral factors affecting pulmonary inflation during acute anaphylaxis in the guinea pig in vivo. Br. J. Pharmacol. Chemother. 30:283-301.

5. Orange, R. P., W. G. Austen, and K. F. Austen. 1971. Immunologic release of histamine and slow-reacting substance of anaphylaxis from human lung. I. Modulation by agents influencing cellular levels of cyclic 3',5'-adenosine monophosphate. J. Exp. Med. 134:136S-148S.

6. Adams, G. K., and L. Lichtenstein. 1979. In vitro studies of antigen-induced bronchospasm: effect of antihistamine and SRS-A antagonist on response of sensitized guinea pig and human airways to antigen. J. Immunol. 122:555-562.

7. Hand, J. M., and C. K. Buckner. 1979. Effects of selected antagonists on ovalbumin-induced contraction of tracheal strips isolated from the actively sensitized guinea pig. Int. J. Immunopharmacol. 1:189-195.

8. Piper, P. J. 1977. Anaphylaxis and the release of active substances in the lungs. Pharmac. Ther. Part B. Gen. Syst. Pharmacol. 3:75-98.

9. Benacerraf, B., Z. Ovary, K. J. Bloch, and E. C. Franklin. 1963. Properties of guinea pig $7 \mathrm{~S}$ antibodies. I. Electrophoretic separation of two types of guinea pig 7 S antibodies. J. Exp. Med. 117:937-949.

10. Ovary, Z., B. Benacerraf, and K. J. Bloch. 1963. Properties of guinea pig $7 \mathrm{~S}$ antibodies. II. Identification of antibodies involved in passive cutaneous and systemic anaphylaxis. J. Exp. Med. 117:951964.

11. Bloch, K. J., F. M. Kourilsky, Z. Ovary, and B. Benacerraf. 1963. Properties of guinea pig $7 \mathrm{~S}$ antibodies. III. Identification of antibodies involved in complement fixation and hemolysis. J. Exp. Med. 117:965-981.

12. Catty, D. 1969. The immunology of nematode infections: Trichinosis in guinea pigs as a model. Monogr. Allergy. 5:1-40.

13. Parish, W. E. 1970. Homologous serum passive cutaneous anaphylaxis in guinea pig mediated by two gamma 1 or gamma 2 type heat stable globulins and non-gamma 1 heat labile reagin. J. Immunol. 105:1296-1298.

14. Dobson, C., D. J. Morseth, and E. J. Soulsby. 1971. Immunoglobulin E-type antibodies induced by Ascaris suum infections in guinea pigs. J. Immunol. 106:128-133.

15. Levine, B. B., H. Chang, and N. M. Vaz. 1971. The production of hapten-specific reaginic antibodies in the guinea pig. J. Immunol. 106:29-33.

16. Ovary, Z., B. Kaplan, and S. Kojima. 1976. Characteristics of guinea pig IgE. Int. Arch. Allergy Appl. Immunol. 51:416-428.

17. Andersson, P. 1980. Antigen-induced bronchial anaphylaxis in actively sensitized guinea-pigs. Pattern of response in relation to immunization regimen. Allergy (Copenh.) 35:65-71. 
18. Andersson, P. 1981. Antigen-induced bronchial anaphylaxis in actively sensitized guinea-pigs. The effect of booster injection and cyclophosphamide treatment. Int. Arch. Allergy Appl. Immunol. 64:249258.

19. Andersson, P. 1980. Antigen-induced bronchial anaphylaxis in actively sensitized guinea-pigs: anti-anaphylactic effects of sodium cromoglycate and aminophylline. Br. J. Pharmacol. 69:467-472.

20. Andersson, P., and H. Bergstrand. 1981. Antigen-induced bronchial anaphylaxis in actively sensitized guinea-pigs: effect of long-term treatment with sodium cromoglycate and aminophylline. Br. J. Pharmacol. 74:601-609.

21. Andersson, P., and R. Brattsand. 1982. Protective effects of the glucocorticoid budesonide, on lung anaphylaxis and actively sensitized guinea pigs: inhibition of IgE- but not of IgG-mediated anaphylaxis. $\mathrm{Br}$. J. Pharmacol. 76:139-147.

22. Graziano, F. M., C. Haley, L. Gunderson, and P. W. Askenase. 1981. IgE antibody production in guinea pigs treated with cyclophosphamide. J. Immunol. 127:1067-1070.

23. Graziano, F. M., L. H. Gundersen, and P. W. Askenase. 1980. Cutaneous basophil reactions mediated by serum rich in guinea pig IgE antibody. Fed. Proc. 36:691.

24. Graziano, F. M., and L. A. Larson. 1982. IgE mediated histamine release from sensitized circulating basophils of the guinea pig. Fed. Proc. 41:823.

25. Wong, D. R., and J. F. Barbaro. 1976. Production of guinea pig $\mathrm{IgG}_{1}$ homocytotropic antibodies to hapten-conjugated homologous serum albumin with different adjuvant combinations. Int. Arch. Allergy Appl. Immunol. 50:155-161.

26. Graziano, F. M., and P. W. Askenase. 1979. Involvement of host Fc receptors in antibody-mediated cutaneous basophil hypersensitivity reactions. J. Immunol. 123:1645-1652.

27. Axen, R. J., J. Porath, and S. Ernbach. 1976. Chemical coupling of peptides and proteins to polysaccharides by means of cyanogen halides. Nature (Lond.). 214:1302-1306.

28. Ovary, Z. 1964. Passive cutaneous anaphylaxis. In Immunological Methods. J. F. Ackroyd, editor. Blackwell Scientific Publications, Ltd., Oxford. 259-301.

29. Brown, S. J., Graziano, F. M., and Askenase, P. W. 1982. Immune cutaneous basophil associated resistance of guinea pigs to ticks: mediation by $7 \mathrm{SIgG}$ antibodies. J. Immunol. 129:2407-2414.

30. Lowry, O. H., N. J. Rosebrough, A. L. Farr, and R. J. Randall. 1951. Protein measurement with the Folin phenol reagent. J. Biol. Chem. 193:265-269.

31. Buckner, C. K., D. E. Clayton, A. A. Ain-Shoka, W. W. Busse, E. C. Dick, and P. Shult. 1981. Parainfluenza 3 infection blocks the ability of a beta adrenergic receptor agonist to inhibit antigen-induced contraction of guinea pig isolated airway smooth muscle. J. Clin. Invest. 67:376-384.

32. Clayton, D. D., W. W. Busse, and C. K. Buckner. 1981. Contribution of vascular smooth muscle to contractile responses of guinea pig isolated lung parenchymal strips. Eur. J. Pharmacol. 70:311-320.

33. van Rossum, J. N. 1963. Cumulative dose-response curves. II. Techniques for the making of dose-response curves in isolated organs and the evaluation of drug parameters. Arch. Int. Pharmacodyn. Ther. 143:299-330.

34. Haynes J. D., R. W. Rosenstein, and P. W. Askenase. 1978. A newly described activity of guinea pig $\mathrm{IgG}_{1}$ antibodies: transfer of cutaneous basophil reactions. J. Immunol. 120:886-892.

35. Katayama, I., K. Nishioka, K. Nishida, and T. Doi. 1982. Non$\mathrm{IgG}_{1}$ nature of cutaneous basophil hypersensitivity factor in contact sensitivity. Int. Arch. Allergy Appl. Immunol. 68:164-169.

36. Askenase, P. W. 1979. Basophil arrival and function in tissue hypersensitivity reactions. J. Allergy Clin. Immunol. 64:79-87.

37. Regal, J. F. 1983. Differential antagonism of IgG and IgE-mediated tracheal contraction. Fed. Proc. 42:444. 